\title{
The Influence of Social Media Against Interest in Buying Kopilogi Products
}

\author{
Salma Fitri Nurfauziah, Nizar Alam Hamdani \\ Universitas Garut \\ Jl. Terusan Pahlawan, Desa Sukagalih, Kecamatan Tarogong Kidul, Garut \\ 24081118018@fkwu.uniga.ac.id
}

\begin{abstract}
This study discusses the influence of social media on interest in buying copilogy products. The relationship used in this study is a causal relationship with 60 Garut domiciled consumer respondents who have already tried their products. The data analysis technique used is simple regression with the application of SPSS 20. The measurement scale used by researchers is the interval scale. This study uses primary data and secondary data obtained from books, journals, literature, scientific works from the internet with relevant sources. The primary data collection technique in this study is an online questionnaire that contains a number of structured statements given to respondents through Google forms and respondents provide answers based on a Likert scale of 1-5, starting from 1 (strongly disagree) to 5 (strongly agree). The conclusion of this research is the significant effect between the influence of Social Media on Kopilogi Buy Interest. Keywords (Social Media) (Buying Interest)(Marketing)
\end{abstract}

Keywords- (Social Media) (Buying Interest)(Marketing)

\section{INTRODUCTION}

In the era technology is increasingly advanced, it cannot be denied that the presence of the internet is increasingly needed in daily life, both in socialization activities, education, business, and others. According to Kotler and Armstrong (in Gita Chairun Nisa, 2013: 2) the Internet is a vast public network of computer networks that connect users around the world to each other and connect them with enormous information storage. Statistics of 2019 internet users in Indonesia in 2018 amounted to 95.2 million, growing by $13.3 \%$ from 2017 which amounted to 84 million users. Internet users also embrace various groups. Based on the age of internet users the maximum age is 15 to 19 years. Then the age of 20 to 24 years, then the age of 25 to 29 years, and ages 30 to 34 years.

Various methods are carried out by business people so that the business they run stays in the midst of existing competition. A business is established and managed to produce a product, both in the form of goods and services. The product is marketed and sold to other parties, both individuals and groups who need the product to meet some of their needs. Thus, good marketing is needed because marketing is a functional area whose role is very strategic in the life of a business.

However, many obstacles experienced by companies in marketing their products, one of which is in offline marketing. Marketing done offline is actually good because it can do product branding. But this certainly requires a large marketing fund, because of the many marketing channels that must be chosen so that a company's product brand is known to the public. But over time, business companies have new ways to carry out marketing activities to reach more targeted consumers, namely social media. Social media provides various alternatives for entrepreneurs and companies in marketing activities, which are more interacting and more social for consumers (Catur Bagus Wicaksono, 2013)

Social media is a computer-based media that facilitates and facilitates users in expressing, interacting, and getting information that can be used by anyone, anytime, and anywhere. Social media is an effective business promotion tool because it can be accessed by anyone, so the promotion network can be wider. Social media is very helpful as a link of information and communication from producers to consumers 
wherever they are and at whatever distance. Social media is an indispensable part of marketing for many companies and is one of the best ways to reach customers and clients. Social media like Instagram, blogs, Facebook, Twitter and YouTube have a number of benefits for companies and are faster than conventional media such as print media, brochures and leaflets.

Buying brands can help as part of consumers' thinking about consumer intentions to buy brands. This is consistent with the statement of Lefa and Laroche (2006) Setiawan (2015) (Indika \& Jovita, 2017), which says that interest is one that discusses individuals who want to buy a particular brand. Madahi and Sukati (2012) (Widayati \& Augustinah, 2019) also said that the interest in buying a compilation of certain product needs after evaluating or perceiving the product whether to buy or not. The influence of consumer perceptions of a product, which will then affect consumer buying interest (Maoyan et al, 2014) (Novila Mileva, 2018). Gunawan and Huarng (2015) expressed opinions about social interactions and asked questions perceived through social media about consumer buying interest. Therefore, Balakrishnan et.al, (2014) (Fury, 2017) suggested that social media be used to promote their products because social media is an important marketing media in the field of market marketing in a fast and efficient way.

The Company's method of using social media is to market its products or services, provide certain information to consumers and promote the products it produces. Social media is used as a marketing communication tool to increase consumer awareness of products, improve product image, and end in increased sales (Kotler and Keller, 2016). Buying interest is an action taken by consumers before making a purchasing decision for a product. Buying interest is the stage of consumer interest in a product and buying interest arises after consumers' awareness and perception of a particular product. According to Maoyan et al (2014) in their research paradigm, buying interest is influenced by social media through consumers' perception of the product.
Theoretically social media used as an important communication tool and has a high role in consumer buying interest.

Indonesia has many companies engaged in the food and beverage business. Researchers collected data from coffee companies in Indonesia. Criteria for the coffee shopper's version, namely: (1) Companies with good product quality (2) Products provided make loyal customers (3) Social media marketing strategies that are able to attract attention.

Table 1

\begin{tabular}{c|l|l}
\hline Ranking & \multicolumn{1}{|c}{$\begin{array}{c}\text { Company } \\
\text { Name }\end{array}$} & $\begin{array}{c}\text { Last } \\
\text { Score }\end{array}$ \\
\hline $\mathbf{1}$ & Starbucks & $\mathbf{8 0 , 0 0}$ \\
\hline $\mathbf{2}$ & Janji Jiwa & $\mathbf{7 5 , 0 0}$ \\
\hline $\mathbf{3}$ & Tekun & $\mathbf{5 5 , 0 0}$ \\
\hline $\mathbf{4}$ & Kopilogi & $\mathbf{4 0 , 0 0}$ \\
\hline
\end{tabular}

Based on Table 1, four coffee companies in Indonesia in the food and beverage business with the most creativity value are Kopilogi 40,00. Kopilogi has been established since August 2015 to create quality products that are widely liked by consumers. Reporting from www.idntimes.com on July 4, 2019, Kopilogi is a place that is often visited by many people, especially among adolescents because it is suitable for hanging out. Kopilogi has its own market share among Garut young people. Kopilogi has a special marketing team on social media to encourage marketing. Shendy, one of the Kopilogi owners, said that the potential of young social media users in Garut is quite good, so that Kopilogi greatly optimizes the use of social media. Kopilogi is indeed focused on targeting young people in Garut, pursuing quantities at affordable prices. Especially with the increasing quantity of consumers, Shendy can reach more young people in his efforts to introduce Garut coffee.

The purpose of this research is to determine the effect of social media on the interest in buying Kopilogi products. From the explanation above, the hypothesis in this study is that social media variables are 
thought to influence consumer buying interest.

This study aims to determine the effect of social media on interest in buying copilogy products. Based on the research objectives, the problem formulation determined by the researcher is What is the Influence of Social Media on Interest in Buying Kopilogi Products?

\section{LITERATURE REVIEW}

\section{Social Media}

Social media is a technology network that is used to create news through internet users and communicate and disseminate information, while social media marketing is a type of internet marketing model to achieve marketing objectives by participating in the scope of social media networks (Maoyan, 2014) (Indika \& Jovita, 2017).

Marketing communication as a way for companies to inform, invite, and remind consumers both directly and indirectly about a product or brand they sell (Kotler \& Keller, 2016). Marketing communication is a way for companies to interact both with internal company (employees) and external parties (consumers, government, competitors, etc.) with the aim of increasing sales and maintaining the company's image. One of the promotional mixes that companies use is social media.

Simplifying sales promotion The company is now choosing practical ways, one of which is using social media. According to Gunnelius (2013: 15) (Indika \& Jovita, 2017). the most common purposes of using social media are:

1. Build relationships : the main benefit of using social media promotion is the ability to actively build relationships with consumers.

2. Brand building : conversations through social media present ways to brand awareness, increase brand recognition and recall and increase brand loyalty.

3. Publicity : Marketing through social media provides outlets where companies can share important information and modify negative perceptions.

4. Promotion: through social media marketing, providing exclusive discounts and providing opportunities for an audience for people to feel valued and special, as well as to fulfill short-term goals.

5. Market Research : use tools from the social web to learn about customers, create demographic profiles and customer behavior, learn about consumer wants and needs, and learn about competitors.

In addition there are other opinions according to Puntoadi (2013: 5) the use of social media functions as follows:

1. The advantage of building personal branding through social media is not knowing tricks or pseudo popularity, because the audience will determine. Various social media can be a medium for people to communicate, discuss, and even gain popularity on socialmedia.

2. Social media provides opportunities to interact more closely with consumers. Social media offers a more individual form of communication. Through social media marketers can find out their consumer habits and interact personally and build deeper attachments.

From the above explanation, it can be concluded that social media is a means of delivering information between people and groups based on their experiences, and by using social media can use the process of delivering that information in a faster and more personal time.

There are three characteristics of social media marketing according to Kotler \& Keller (2016), namely:

1. Rich

Rich here means the company provides complete information and in accordance with what consumers want. While indicators from the rich, namely: (1) receive complete and indepth information (2) receive information in accordance with what consumers want.

2. Interactive

Interactive is something related to two-way communication and interconnected to take action, be active, and interact with each other and have reciprocity between one another. In marketing communications on social media, companies provide interactive information in the form of images or photos, sounds, graphics, videos, animations and so on to create interactions with consumers. While the indicators of interactive, namely: 
providing interactive information in the form of photos (2) providing interactive information in the form of sound (3) providing interactive information in the form of video.

\section{Current}

The latest company information must provide messages and information in accordance with the phenomenon that is happening. While the indicators are up to date, which provides the most current / up to date messages and information.

\section{Buying Interest}

The fact shows that knowing the needs and desires of consumers is not easy. The consumer can change his mind at the last minute. Of course marketers expect consumers to be positive that is willing to buy the goods offered. To attract or foster consumer buying interest marketers must first understand how consumers decide.

According to Kotler and Keller who were translated by Benyamin Molan (2012: 568) (Anto, 2018) stated that buying interest is a stage carried out by consumers before planning to buy a product. The Ashari (2012: 246) (Rachmawan et al., 2018) defines that buying interest is a sense of interest experienced by consumers towards a product (goods or services) that is influenced by attitudes outside the consumer and within the consumer itself. According to Davidson in Tjiptono $(2015 ; 140)$ consumer buying interest can be interpreted as follows Buying interest reflects the desire and desire of consumers to buy a product.

According to Ferdinand (2002: 129) buying interest can be identified through the following indicators:

1. Transactional interest, which is a person's tendency to buy products.

2. Reference of interest, i.e. one's tendency to refer products to other people.

3. Preferential interest, namely interests that describe the behavior of someone who has a primary preference on the product. This preference can only be replaced if something happens with the product preference.

4. Explorative interest, this interest illustrates the behavior of someone who is always looking for information about the product he is interested in and looking for information to support the positive quality of the product.

Previous research used is as a basis in the preparation of research. The aim is to find out the results that have been done by previous researchers, as well as comparisons and figures that can support subsequent similar studies. The study used is about social media that has an effect on buying interest. The following is a table of previous studies relating to the research title:

Table 1.2

\begin{tabular}{|c|c|c|c|c|}
\hline No & $\begin{array}{c}\text { Researcher's } \\
\text { Name and } \\
\text { Research Title }\end{array}$ & $\begin{array}{c}\text { Equation } \\
\text { of } \\
\text { Research } \\
\text { Variables }\end{array}$ & $\begin{array}{c}\text { Differen } \\
\text { ces in } \\
\text { Researc } \\
\text { h } \\
\text { Variable } \\
\quad \mathbf{s} \\
\end{array}$ & $\begin{array}{c}\text { Research } \\
\text { Result }\end{array}$ \\
\hline 1. & $\begin{array}{c}\text { Febian Risa } \\
\text { and Harrie } \\
\text { Lutfie (2017) } \\
\text { The Influence } \\
\text { of Social Media } \\
\text { and Sales Kit on } \\
\text { Consumer } \\
\text { Purchase } \\
\text { Interests at } \\
\text { Nexa Hotel } \\
\text { Bandung in } \\
2017 \\
\text { Journal of } \\
\text { Management } \\
\text { Vol.3, No.2 }\end{array}$ & $\begin{array}{l}\text { Having } \\
\text { the same } \\
\text { free social } \\
\text { media } \\
\text { variables } \\
\text { and the } \\
\text { dependent } \\
\text { variable } \\
\text { buying } \\
\text { interest }\end{array}$ & $\begin{array}{c}\text { Add } \\
\text { sales kits } \\
\text { as } \\
\text { independ } \\
\text { ent } \\
\text { variables } \\
\text { and have } \\
\text { differenc } \\
\text { es in } \\
\text { place } \\
\text { and time } \\
\text { of } \\
\text { research }\end{array}$ & $\begin{array}{l}\text { There is a } \\
\text { positive } \\
\text { and } \\
\text { significant } \\
\text { influence } \\
\text { between } \\
\text { social } \\
\text { media and } \\
\text { sales kits } \\
\text { on } \\
\text { consumer } \\
\text { buying } \\
\text { interest. }\end{array}$ \\
\hline 2. & $\begin{array}{c}\text { (Pradipta, } \\
\text { 2015) } \\
\text { The Influence } \\
\text { of Brand Image, } \\
\text { Social Media } \\
\text { Against Interest } \\
\text { in Onemed } \\
\text { Thermometer } \\
\text { Consumer } \\
\text { Purchase in } \\
\text { Surabaya } \\
\text { Journal of } \\
\text { Science and } \\
\text { Research } \\
\text { Management } \\
\text { Vol 4, No. } 7\end{array}$ & $\begin{array}{l}\text { Having } \\
\text { the same } \\
\text { free social } \\
\text { media } \\
\text { variables } \\
\text { and the } \\
\text { dependent } \\
\text { variable } \\
\text { buying } \\
\text { interest }\end{array}$ & $\begin{array}{l}\text { Adding } \\
\text { brand } \\
\text { image as } \\
\text { an } \\
\text { independ } \\
\text { ent } \\
\text { variable } \\
\text { has a } \\
\text { differenc } \\
\text { e in time } \\
\text { and } \\
\text { place of } \\
\text { research }\end{array}$ & $\begin{array}{l}\text { There is a } \\
\text { positive } \\
\text { and } \\
\text { significant } \\
\text { influence } \\
\text { between } \\
\text { brand } \\
\text { image, } \\
\text { social } \\
\text { media on } \\
\text { consumer } \\
\text { buying } \\
\text { interest }\end{array}$ \\
\hline 3. & $\begin{array}{c}\text { (Ambarwati, } \\
\text { 2015) } \\
\text { The Effect of } \\
\text { Brand Image } \\
\text { on Purchasing } \\
\text { Interest } \\
\text { (Survey on } \\
\text { Brawijaya } \\
\text { University } \\
\text { Students }\end{array}$ & $\begin{array}{c}\text { Has a } \\
\text { variable } \\
\text { equation } \\
\text { tied to } \\
\text { buying } \\
\text { interest }\end{array}$ & $\begin{array}{c}\text { There } \\
\text { are no } \\
\text { social } \\
\text { media } \\
\text { independ } \\
\text { ent } \\
\text { variables } \\
\text { and there } \\
\text { are } \\
\text { differenc }\end{array}$ & $\begin{array}{c}\text { There is a } \\
\text { positive } \\
\text { and } \\
\text { significant } \\
\text { influence } \\
\text { between } \\
\text { brand } \\
\text { image on } \\
\text { consumer }\end{array}$ \\
\hline
\end{tabular}




\begin{tabular}{|c|c|c|c|c|}
\hline & $\begin{array}{c}\text { Using } \\
\text { Toothpaste) } \\
\text { Brawijaya } \\
\text { Journal Vol. } 25 \\
\text { No 1 }\end{array}$ & & $\begin{array}{l}\text { es in the } \\
\text { time and } \\
\text { place of } \\
\text { research }\end{array}$ & $\begin{array}{l}\text { buying } \\
\text { interest }\end{array}$ \\
\hline 4. & $\begin{array}{c}\text { (Arief \& } \\
\text { Millianyani, } \\
\text { 2015) } \\
\text { The influence of } \\
\text { social media } \\
\text { marketing } \\
\text { through } \\
\text { Instagram on } \\
\text { the interest of } \\
\text { buying sugar } \\
\text { tribe } \\
\text { consumerse- } \\
\text { procceding of } \\
\text { Management } \\
\text { Vol. 2, No.3 }\end{array}$ & $\begin{array}{l}\text { Having } \\
\text { the } \\
\text { same free } \\
\text { social } \\
\text { media } \\
\text { variables } \\
\text { and the } \\
\text { dependent } \\
\text { variable } \\
\text { buying } \\
\text { interest. }\end{array}$ & $\begin{array}{l}\text { Have a } \\
\text { differenc } \\
\mathrm{e} \text { in } \\
\text { time and } \\
\text { place } \\
\text { of } \\
\text { research. }\end{array}$ & $\begin{array}{c}\text { There is a } \\
\text { positive } \\
\text { and } \\
\text { significant } \\
\text { influence } \\
\text { between } \\
\text { social } \\
\text { media } \\
\text { through } \\
\text { Instagram } \\
\text { on } \\
\text { consumer } \\
\text { buying } \\
\text { interest }\end{array}$ \\
\hline 5. & $\begin{array}{l}\text { Mila Yuni } \\
\text { Pratiwi } \\
\text { (2017) } \\
\text { Influence of } \\
\text { Price, Social } \\
\text { Media and } \\
\text { Brand Image } \\
\text { on Interest in } \\
\text { Buy 2beat } \\
\text { Shoes in } \\
\text { Surabaya } \\
\text { Journal of } \\
\text { Management } \\
\text { Science and } \\
\text { Research Vol 6, } \\
\text { Number 7 }\end{array}$ & $\begin{array}{l}\text { Having } \\
\text { the } \\
\text { same free } \\
\text { social } \\
\text { media } \\
\text { variables } \\
\text { and the } \\
\text { dependent } \\
\text { variable } \\
\text { buying } \\
\text { interest }\end{array}$ & $\begin{array}{c}\text { Add } \\
\text { price- } \\
\text { free } \\
\text { variables } \\
\text {, brand } \\
\text { image } \\
\text { and have } \\
\text { different } \\
\text { place } \\
\text { and time } \\
\text { of } \\
\text { research }\end{array}$ & $\begin{array}{l}\text { There is a } \\
\text { positive } \\
\text { and } \\
\text { significant } \\
\text { influence } \\
\text { between } \\
\text { price, } \\
\text { social } \\
\text { media } \\
\text { and brand } \\
\text { image on } \\
\text { consumer } \\
\text { buying } \\
\text { interest. }\end{array}$ \\
\hline
\end{tabular}

Source: Researcher Data

Based on previous research seen from table 1.2 it can be said that there are differences and similarities in both the title or variable of the method under study, the place or object of the study, as well as the time of the research. Judging from the title or variable examined, that there have been many studies using social media variables and buying interest so that the author can refer to previous research.

\section{RESEARCH HYPOTHESIS}

Sugiono (2017: 63) (Mallisa, 2017) states that the hypothesis is a temporary answer to the research problem formulation, where the problem formulation is stated in the form of sentence statements. It is said temporarily, because the answers given are only based on relevant theories, not yet based on empirical facts obtained through data collection or questionnaires. Then the hypothesis in the following research is as follows:

Ha: Social media influences buying interest

Ho: Social media has no effect on buying interest

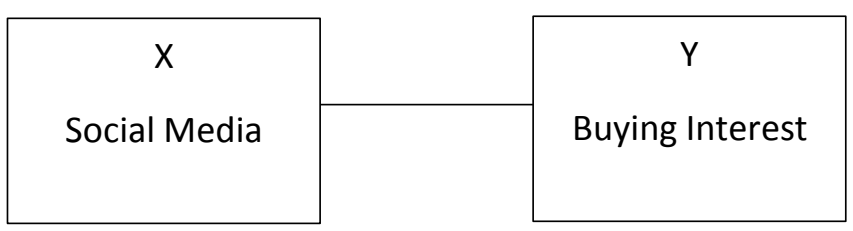

\section{Methodology/Materials}

This type of research that will be used is a quantitative research type that is research that asks the relationship between two or more variables, Sugiyono (2013: 57). The relationship used in this study is a causal relationship. Casual relationship is a relationship that is causal, which consists of independent variables (variables that affect) and dependent (variables that are affected) according to Sugiyono (2013: 59). This study aims to determine the influence of variables, namely the variable (X) Effect of Social Media on (Y) Interest in Kopilogi products.

The way to obtain data on a causal research design is a survey. According to Sugiyono (2014: 2) in (Fatimah, 2017) the research method is a research method is a scientific way to obtain data with specific purposes and uses. In this study the authors used survey research methods. Survey research is conducted to make generalizations from observations and the results will be more accurate. The survey method is used to get data from a particular place that is natural (not artificial). Researchers treat data collection, for example by giving questionnaires.

Population is a generalization area consisting of: objects / subjects, which have certain qualities and characteristics that are applied by researchers to be studied and then drawn conclusions, Sugiyono 34 (2013: 117). The target population is Kopilogi consumers who have consumed Kopilogi products to provide an ideal population limit, the unit of analysis of this study is Kopilogi consumers as individuals. While the observation unit of this study is the consumer. Tabachnick and Fidel in Dwi Suhartanto (2014: 330 ), give a formula for the size of the sample by referring to the number of independent variables, namely $\mathrm{N} \geq 52+8 \mathrm{i}$ ( $\mathrm{i}$ is the number of independent 
variables). Then, the number of samples to be used was 60 respondents.

Respondent criteria determined by researchers in this study are men and women who live in the city of Garut. Respondents have consumed Kopilogi products to find out the influence of social media on buying interest in Kopilogi products.

Data analysis techniques in quantitative research use statistics. Sugiyono (2008: 261) states that: "Simple linear regression is based on the functional or causal relationship of an independent variable with a dependent variable. The program used to conduct data analysis using linear regression is the Statistical Product and Service Solution (SPSS). The measurement scale used by researchers is the interval.

Dwi Suhartanto (2014: 174), defines the interval scale as a scale that allows researchers to perform arithmetic calculations on data collected from respondents. The measurement has no real zero value. Measurement of consumer attitudes that are commonly used in this study is a Likert scale. Likert scale is a scale that asks respondents to respond to the extent to which they agree or disagree about an object that is perceived as strongly agree, agree, doubt, disagree and strongly disagree.

\section{RESULT}

\section{Respondent Characteristics}

Respondents in the study were 60 Kopilogi consumers, with the following characteristics: (1) 21 respondents or $35.5 \%$ were male and 39 respondents or $65.5 \%$ were female. (2) 27 respondents or $44.6 \%$ aged $<19$ years, 32 respondents or $53.7 \%$ aged $20-31$ years, and 1 respondent or $1.7 \%$ aged $31-40$ years (3) 56 respondents or $93.4 \%$ were recorded as students, 3 respondents or $5 \%$ were recorded as employees and 1 respondent or $1.6 \%$ were recorded as not working / not working, and (4) 7 respondents or $11.6 \%$ had consumed Kopilogi since 2015, 3 respondents or $5 \%$ consumed Kopilogi since 2016, 10 respondents or $17.4 \%$ consumed Kopilogi since 2017, 13 respondents or $22.3 \%$ consumed Kopilogi since 2018, 20 respondents or $32.2 \%$ consumed Kopilogi since 2019, and 7 respondents or $11.6 \%$ have consumed Kopilogi since 2020 .

\section{Dimentional Charecteristics \\ Social Media}

Social Media Variable has 3 dimensions, namely Giving Information, Interaction Place, and Inviting. The questionnaire data will be explained in Table 2. Average Values of Variables and Social Media Dimensions of the Kopilogi.

\begin{tabular}{|c|c|c|c|}
\hline No & Dimensions & Averange & Category \\
\hline & Social Media & & \\
\hline 1. & $\begin{array}{l}\text { Giving } \\
\text { Information }\end{array}$ & 51,23 & $\begin{array}{l}\text { Strongly } \\
\text { Approve }\end{array}$ \\
\hline 2. & Interaction Place & 48,8 & $\begin{array}{l}\text { Strongly } \\
\text { Approve }\end{array}$ \\
\hline 3. & Inviting & 41,7 & Approve \\
\hline
\end{tabular}

Based on the results of data processing with Excel on 60 online consumer respondents, the average value of the Social Media variable is very strongly approved. Giving Information is described by consumers perceptions of the information conveyed by the company. Where to interact is described by the existence of social media makes it easy for consumers to ask about the product. Inviting is illustrated by the message delivered through photos and videos inviting consumers to buy Kopilogi products.

\section{Buying Interest}

Variable Interest in Buy has 3 dimensions, namely Buying Interest, Explorative, and Tendency to Refer Product. Questionnaire data will be explained in Table 3. Average Value of Variables and Dimensions of Buying Interest.

\begin{tabular}{c|l|l|l}
\hline $\begin{array}{c}\text { No } \\
.\end{array}$ & Dimentions & Averange & Category \\
\hline $\mathbf{1 .}$ & Buying Interest & & \\
\hline $\mathbf{2 .}$ & Explorative & 48,8 & $\begin{array}{l}\text { Strongly } \\
\text { Approve }\end{array}$ \\
\hline $\mathbf{3 .}$ & $\begin{array}{l}\text { Tendency to } \\
\text { Refer Product }\end{array}$ & $\mathbf{4 2 , 1}$ & $\begin{array}{l}\text { Appongly } \\
\text { Approve }\end{array}$ \\
\hline
\end{tabular}

Based on the results of data processing with Excel on 60 respondents, the average value of the Kopilogi purchase decision variable is very much in agreement. Interest in buying is illustrated by consumers perception of the large 
selection of products offered by Kopilogi companies. Explorative is described by information obtained by consumers. The tendency to reference a product is illustrated by consumers who recommend the product.

\section{Analysis of Social Media Effects on Buying Interest}

The first analysis was conducted to determine the value of the regression coefficient on each dimension of social media to the dimensions of buying interest. The results of the analysis can be seen in Table 3. Regression Coefficients

\begin{tabular}{|c|c|c|c|c|c|c|}
\hline \multicolumn{2}{|c|}{ Dimentions } & \multirow{2}{*}{$\begin{array}{l}\text { Coefficient } \\
\text { Regression }\end{array}$} & \multirow{2}{*}{$\begin{array}{l}\text { Standart } \\
\text { Error }\end{array}$} & \multirow[t]{2}{*}{ TValue } & \multirow[t]{2}{*}{ Sig } & \multirow[t]{2}{*}{ Explanation } \\
\hline $\mathrm{x}$ & $\mathrm{Y}$ & & & & & \\
\hline \multicolumn{2}{|l|}{ Constant } & 3,183 & 0,239 & 13,294 & 0,000 & \\
\hline Giving Information & \begin{tabular}{|l|} 
Purchase interest \\
\end{tabular} & 0,122 & 0,102 & 1,199 & 0,233 & No React \\
\hline Interaction Place & & 0,306 & 0,139 & 2,206 & 0,031 & React \\
\hline Inviting & & 1,139 & 0,107 & 1,806 & 0,073 & No React \\
\hline \multicolumn{2}{|l|}{ Constant } & 2,610 & 0,408 & 6,388 & 0,005 & \\
\hline Giving Information & Explorative & 0,298 & 0,104 & 2,855 & 0,005 & React \\
\hline Interaction Place & & 0,130 & 0,138 & 0,941 & 0,351 & No React \\
\hline Inviting & & 0,063 & 0,109 & 0,567 & 0,567 & No React \\
\hline \multicolumn{2}{|l|}{ Constant } & 2,973 & 0,516 & 5,763 & 0,000 & \\
\hline Giving Information & Tendency to & 0,242 & 0,129 & 1,872 & 0,066 & No React \\
\hline Interaction Place & refer product & 0,407 & 0,119 & 3,436 & 0,001 & React \\
\hline Inviting & & 0,242 & 0,129 & 1,872 & 0,066 & No React \\
\hline
\end{tabular}

Source: Data processing with SPSS 20 for Windows on 60 respondents

The second analysis was conducted to determine the level of relationship between social media and buying interest. Testing is done by using the value of the relationship coefficient and the coefficient of determination contained in Table 4. Model Summary.

\section{Model Summary}

\begin{tabular}{lllll}
\hline Model & $\mathbf{R}$ & $\begin{array}{l}\mathbf{R} \\
\text { Square }\end{array}$ & $\begin{array}{l}\text { Adjusted } \\
\text { R Square }\end{array}$ & $\begin{array}{l}\text { Std. } \\
\text { Error of } \\
\text { the } \\
\text { Estimate }\end{array}$ \\
\hline 1 &, $759^{a}$ &, 577 &, 553 & $\mathbf{1 , 9 3 1 8 4}$ \\
\hline
\end{tabular}

a. Predictors: (Constant), Social_Media

b. Dependent Variable: Buying_Interest

Based on Table 4, the coefficient of the relationship between social media and buying interest is expressed with an $\mathrm{R}$ value of 0.759 .
Akdon (2010: 217) in Diamond, if the coefficient interval is $0.60-0.799$, it shows the level of relationship between media issues with buying interest is high. While the $\mathrm{R} 2$ value of 0.577 is expressed as a coefficient of determination between social media and buying interest. That is, social media affect buying interest by $57.7 \%$. While $42.3 \%$ are other independent variables outside the regression model.

The third analysis is carried out to find out whether the social media dimension influences buying interest. In this study there are main hypotheses to be tested, namely Ha: Social Media significantly influences Buy Interest. The test is carried out using the significance values contained in table 4.

\begin{tabular}{|l|r|r|r|r|r|}
\hline \multicolumn{7}{|c|}{ ANOVA $^{\mathrm{a}}$} \\
\hline Model & \multicolumn{1}{|c|}{ Sum of Squares } & \multicolumn{1}{c|}{ df } & Mean Square & \multicolumn{1}{c|}{ F } & Sig. \\
\hline Regression & 274,352 & 3 & 91,451 & 24,505 & \\
\hline Residual & 201,527 & 54 & 3,732 & & \\
\hline Total & 475,879 & 57 & & & \\
\hline a. Dependent Variable: Buying_Interest \\
\hline b. Predictors: (Constant), Social_Media \\
\hline
\end{tabular}

Source: Data processing with SPSS 20 for Windows on 60 respondents.

Based on Table 4, if the significance value $0.00<0.05$ then Ha is accepted. That is, Social Media significantly influences Buy Interest. The results of this study are assumed to be widely applied outside the focus of research on the influence of Social Media on Purchasing Interest of Kopilogi products.

\section{CONCLUSION AND SUGGESESTION}

After analyzing the theories and the results of previous researchers, researchers get results to answer the problem formulation with the following conclusions:

1. Research conducted to find out how the influence of Social Media on Purchase Interest is carried out with a case study of Kopilogi consumers who have consumed Kopilogi products.

2. There is a significant influence between Social Media on Interest in Buying Kopilogi products, meaning that there is an influence of Social Media on Interest in Buying Kopilogi products. 
3. After conducting research, researchers suggest that each company conducts marketing on social media to attract products to buy. Suggestions for further research that researchers are advised to use many sources or references both in journals and in books so that research results can be done more accurately.

\section{REFERENCE}

[1] Ambarwati, M. (2015). PENGARUH CITRA MEREK TERHADAP MINAT BELI (Survei Pada Mahasiswa Universitas Brawijaya Yang Menggunakan Pasta Gigi Pepsodent). Jurnal Administrasi Bisnis S1 Universitas Brawijaya.

[2] Anto, R. (2018). PENGARUH STORE ATMOSPHERE DAN PROMOSI TERHADAP MINAT BELI (Survey pada Pengunjung Distro Maternal Bandung). In Institutional Repositories \& Scientific Journals. https://doi.org/10.1017/CBO9781107415324.00 4 Argote, L. (2012). Organizational learning: Creating, retaining and transferring knowledge.Springer Science \& Business Media.

[3] Arief, G. M., \& Millianyani, H. (2015). PENGARUH SOCIAL MEDIA MARKETING MELALUI INSTAGRAM TERHADAP MINAT BELI KONSUMEN SUGAR TRIBE. E-Proceeding of Management. https://doi.org/10.3724/SP.J.1047.2015.01269

[4] Broekhuizen, T. L. J., Emrich, O., Gijsenberg, M. J., Broekhuis, M., Donkers, B., \& Sloot, L. M. (2019). Digital platform openness: Drivers , dimensions and outcomes. Journal of Business Research, May, 1-13. https://doi.org/10.1016/j.jbusres.2019.07.001

[5] Broekhuizen, T. L. J., Emrich, O., Gijsenberg, M. J., Broekhuis, M., Donkers, B., \& Sloot, L. M. (2019). Digital platform openness: Drivers , dimensions and outcomes. Journal of Business Research, May, 1-13. https://doi.org/10.1016/j.jbusres.2019.07.001

[6] Cahyono, A. S. (2016). Pengaruh media sosial terhadap perubahan sosial masyarakat di Indonesia. Jurnal Ilmu Sosial \& Ilmu Politik Diterbitkan Oleh Fakultas Ilmu Sosial \& Politik, Universitas Tulungagung.

[7] Catur Bagus Wicaksono, K. (2013). Mengukur Efektivitas Social Media Bagi Perusahaan. Binus Business Review. https://doi.org/10.21512/bbr.v4i1.1419

[8] Eckhardt, G. M., Belk, R., \& Devinney, T. M. (2010). Why don't consumers consume ethically? Journal of Consumer Behaviour. https://doi.org/10.1002/cb.332

[9] Elvina, E. (2019). Pengaruh Penggunaan Media Sosial Terhadap Pengembangan Usaha Kecil Menengah (Ukm). Ecobisma (Jurnal Ekonomi, Bisnis Dan Manajemen), 2(1), 106-118. https://doi.org/10.36987/ecobi.v2i1.722

[10] Fatimah, S. (2017). Analisis Service Quality Menggunakan Metode Fishbone Diagram (Studi Kasus pada Bank bjb Buah Batu Bandung Tahun 2017). E-Proceeding of Applied Science.

[11] Fury, F. R. (2017). Keputusan Pembelian Produk Hijab pada Toko Online MiuLan di Semarang. Fakultas Ekonomi \& Bisnis Universitas Dian Nuswantoro, Semarang.

[12] Holt, D. B. (1995). How Consumers Consume: A Typology of Consumption Practices. Journal of Consumer Research. https://doi.org/10.1086/209431

[13] Indika, D. R., \& Jovita, C. (2017). Media Sosial Instagram Sebagai Sarana Promosi Untuk Meningkatkan Minat Beli Konsumen. Jurnal Bisnis Terapan, 1(01), 25. https://doi.org/10.24123/jbt.v1i01.296

[14] Kaplan, A., \& Mazurek, G. (2018). Social media. In Handbook of Media Management and Economics: $\quad$ Second Edition. https://doi.org/10.4324/9781315189918

[15] Kartikasari, D., Arifin, Z., \& Hidayat, K. (2013). Pengaruh Perilaku Konsumen Terhadap Keputusan Pembelian. Jurnal Administrasi Bisnis.

[16] Kumadji, R. D. A., Kumadji, S., \& Yulianto, E. (2015). DAMPAKNYA PADA KEPUTUSAN PEMBELIAN ( Survei Pada Konsumen Non-Member Tupperware Di Kota Malang ). Jurnal Administrasi Bisnis.

[17] Kurniasari, M., \& Budiatmo, A. (2018). Pengaruh Social Media Marketing, Brand Awareness Terhadap Keputusan Pembelian Dengan Minat Beli Sebagai Variabel Intervening Pada J.Co Donuts \&amp; Coffee Semarang. Jurnal Administrasi Bisnis, 7(1), 25. https://doi.org/10.14710/jab.v7i1.22571

[18] Mallisa, E. I. (2017). Pengaruh Kompetensi 
Karyawan Dan Budaya Organisasi Terhadap Prestasi Kerja Karyawan PT Telkom Indonesia. Repository, 23-70. http://repository.unpas.ac.id/30050/5/7.

BAB II.pdf

[19] Maria, C. (2006). Development of Application of Questionnaire Making For Web Based Survey.

[20] Nadda, V. K., Dadwal, S. S., \& Firdous, A. (2015). Social media marketing. In Handbook of Research on Integrating Social Media into Strategic Marketing. https://doi.org/10.4018/978-1-4666-83532.ch021

[21] NOVILA MILEVA, D. (2018). PENGARUH SOCIAL MEDIA MARKETING DAN PERSEPSI KUALITAS TERHADAP NIAT BELI SURABAYA SNOWCAKE (Studi pada Masyarakat Surabaya Timur). Jurnal Ilmu Manajemen (JIM).

[22] Nurgayatri, A. R. (2 C.E.). Pengaruh Promosi Online Pada Media Sosial Terhadap Keputusan Online Promotion Effect on Social Media Consumer Buying Decisions Brand Elmeira. Fakultas Ekonomi Dan Bisnis, Universitas Telkom.

[23] Pradipta, H. O. (2015). Pengaruh citra merek, periklanan terhadap minat beli konsumen thermometer onemed di surabaya. Ilmu Dan Riset https://doi.org/10.4244/EIJV9I5A94

[24] Putri, S. D., \& Tresnati, R. (2018). Pengaruh Pemasaran Media Sosial terhadap Minat Beli ( Survey Pelanggan Pada Toko Pakaian Hijab Kembar Shop Bandung ). Prosiding Manajemen, Vol. 4(No. 1), 161-168.

[25] Putri, W. S. R., Nurwati, N., \& S., M. B. (2016). Pengaruh Media Sosial Terhadap Perilaku Remaja. Prosiding Penelitian Dan Pengabdian Kepada Masyarakat, 3(1). https://doi.org/10.24198/jppm.v3i1.13625

[26] Rachmawan, R. F., Rachma, N., \& Hufron, M. (2018). Pengaruh Iklan Internet dan Electronic Word Of Mouth (EWOM) terhadap Minat Beli Situs Online Shopee pada Mahasiswa di FEB Manajemen Universitas Islam Malang. E-Jurnal Riset Manajemen PRODI MANAJEMEN Fakultas Ekonomi Unisma.
[27] Raheni, C. (2018). Pengaruh Media Sosial Terhadap Minat Beli Konsumen Studi Kasus Mahasiswa The Effect Of Social Media On Consumer Buying Interest Study Case Study. Jurnal Sinar Manajemen, Vol. 5(No. 2), 82-85.

[28] Romero, D. M., Galuba, W., Asur, S., \& Huberman, B. A. (2011). Influence and passivity in social media. Lecture Notes in Computer Science (Including Subseries Lecture Notes in Artificial Intelligence and Lecture Notes in Bioinformatics). https://doi.org/10.1007/978-3-642-238086_2

[29] Ruíz, A. A. B. (2015). Pengaruh Penggunaan Media Sosial Terhadap Pengembangan Usaha Kecil Menengah (UKM). 3(2), 54-67. http://repositorio.unan.edu.ni/2986/1/5624.p df

[30] Ryan Tio, P., Khasanah, I., \& Manajemen, J. (2016). Pengaruh Citra Merek, Kualitas Produk, Desain Produk, Dan Persepsi Harga Terhadap Minat Beli Konsumen Pada Produk Merek Vicious Colony Di Werehouse Store, Banjarmasin. Diponegoro Journal Of Management.

[31] Setiawati, M. (2015). Pengaruh Media Sosial Terhadap Minat Beli Konsumen. Sistem Informasi Akuntansi.

[32] Sugianto Putri, C. (2018). Pengaruh Media Sosial Terhadap Keputusan Pembelian Konsumen Cherie Melalui Minat Beli.

[33] PERFORMA: Jurnal Manajemen Dan Start-Up Bisnis.

[34] Wardhani, W., Sumarwan, U., \& Yuliati, L. N. (2016). Pengaruh Persepsi dan Preferensi Konsumen terhadap Keputusan Pembelian Hunian Green Product. Jurnal Manajemen Dan Organisasi.

https://doi.org/10.29244/jmo.v6i1.12183

[35] Widayati, W., \& Augustinah, F. (2019). Pemanfaatan Media Sosial Sebagai Sarana Promosi Makanan Ringan Kripik Singkong Di Kabupaten Sampang. Dialektika: Jurnal Ekonomi Dan Ilmu Sosial. 